\title{
Child Labour Exploitation in The Tourism Industry on The Island of Lombok
}

\author{
S Syafruddin* \\ Sociology Education Study Program \\ University of Mataram \\ Mataram, Indonesia \\ syafruddin_fkip@unram.ac.id
}

\author{
Hairil Wadi \\ Sociology Education Study Program \\ University of Mataram \\ Mataram, Indonesia \\ wadifkipunram@email.com
}

\author{
R Rispawati \\ Civic Education Study Program \\ University of Mataram \\ Mataram, Indonesia \\ rispa64@gmail.com
}

\author{
S Suud \\ Sociologi Education Studi Program \\ University of Mataram \\ Mataram, Indonesia \\ suud.fkip@unram.ac.id
}

\author{
Ni Made Novi Suryanti \\ Sociologi Education Studi Program \\ University of Mataram \\ Mataram, Indonesia \\ novifkip@unram.ac.id
}

\begin{abstract}
This paper aims to identify and map the forms of exploitation of child labor in the tourism industry. To understand the phenomenon of child workers, the researchers used a qualitative research approach with a case study method. The research subjects were child workers in which the data were collected at the individual level of the child worker. In order to check the validity of the data, triangulation of data sources and triangulation of data collection methods (observation, interviews, documentation study) were conducted. The results of the research found out that the forms of exploitation of children that work in the tourism industry include: a. There was a use of the time that was not according to the age of the children. $b$. The time in which the children work was beyond their ability and was in an unreasonable limit, the works of the children were not in accordance with the age conditions, $c$. There was no free time for the children to play, $d$. There was a form of coercion from other people to do work, f. The low wages earned do not match with the amount of time worked by the children. Taking the phenomenon of child labor in tourist destinations on the island of Lombok into account, the local government needs to approach parents so as not to employ underage children. Parents must have a high awareness of educating their children to a better level so that in the future it would be easier for the children to get a proper job in the world of work. In addition, it is necessary to empower working children to be awarded scholarships so that they are motivated to study and attend school. To the parents, the government also needs to increase the capacity of parents, in the form of training on the way to do entrepreneurship, and provide venture capital to support the survival of the family. Thus, children from poor families can go to school, and they do not have to work.
\end{abstract}

Keywords - exploitation, industry, child laborer, tourism.

\section{INTRODUCTION}

Constitution Law Number 35 of 2014, Article 1 Paragraph 2 concerning the protection of child labor states that child protection is all activities to guarantee and protect children and their rights so that they can live, grow, develop and participate optimally in accordance with dignity and humanity, as well as can receive protection from exploitation, violence, and discrimination. The study found that the phenomenon and problem of child labor is the provision of workloads to minors. Children, who should have spent their time playing, spent their childhoodworking. Apart from that, the fact is that in rural areas, 8-year-old children in which they help their parents earn a living is a common thing, and even continues to develop until this research was conducted. Furthermore, in families with weak economies, children are considered to have economic benefits for the family. The existence of children is considered a factor of production that helps parents to carry out economic activities so that the presence of children is expected to overcome economic problems that surround the family. The phenomenon of child labor appears in many urban communities, namely around 2.1 million child laborers, including homeless children. At an age that should still receive protection and management, child laborers face the harshness of urban life [1-2].

The existence of working children can be viewed from the perspective of the wage labor market. From the point of view of the logic of supply, poverty is the main reason that encourages children to work in order to ensure the survival of themselves and their families. The encouragement can come from the children themselves and from their parents. They do work, so that they can meet their own needs, and can reduce the costs incurred by their family [3].

According to the International Labour Organization (ILO), more than 250 million children aged 5-14 years are forced to work and lose their childhood because they have to devote their time to be involved in the production process, both within their own families and in other places. A report from the ILO, $61 \%$ of child laborers are spread across Asia, and for Indonesia, it is estimated that there are around 5 to 6.5 million child laborers, some even estimate that more are spread across various large sectors and household businesses [3]. Data from the LPA (Child Protection Agency) of NTB Province in 2003, there are 5 locations that have been the most vulnerable to exploitation including Banyumulek, OtakKokok, Sade, Gili, Kuta, and Senggigi. The exploitation that is carried out has been in the form of economic and sexual exploitation. In cases of economic exploitation of craftsmen, there were 115 cases, souvenir traders 59 cases, hawkers 39 cases, hotel maids 35 cases, and fishermen 29 cases. Then in cases of sexual exploitation, 16 cases of prostituted children were sold and sodomized in 3 cases each [4]. 
In this research, the exploitation of children refers to discriminatory attitudes or arbitrary treatment of the children by their family or society. Forcing children to do something for economic, social, or political interests without paying attention to the right of the children that is to get protection in accordance with their physical, psychological \& social status. Another definition of child exploitation is using children unethically for the good or benefit of parents and others [1].

However, the definition of child labor in this research is limited to children who do work routinely for their parents or for other people, which requires a large amount of time, whether they receive a reward or not. Child laborers work directly or indirectly to increase the income of their family or household. The employment method that is applied to child labor takes various forms, namely work labor, apprenticeship, and family labor. In this research, child labor is understood as all working children in the age of 5-12 years, regardless of their working hours, children aged 13-14 years that work more than 15 hours per week, and 15-17 age years old children that work more than 40 hours per week. The regulations of Indonesia define 15 years of age as the minimum age for public works. [5]

In the preliminary study that was carried out in December 2019 in Senggigi tourist destination area and the special economic area of KuteMandalika Beach, Central Lombok, a number of children that work in tourism industry services were found, such as traveling agency, shopkeepers and restaurants, and some, at night, take part as a dancer in bars and cafes at night.

Based on the phenomenon of child labor in the tourist destinations on the island of Lombok, the problemsof this research were formulated inthe form of exploitation of child labor in the tourism industry. The results of this study were expected to have a very valuable urgency, in the form of contributing thoughts and data in making policies and compiling practical programs related to child labor. Especially policies, strategies, and programs that are oriented towards the child laborers so that there are conditions that can increase resources and levels of education and skills of the child laborers, as well asprotecting them from all forms of marginalization and exploitation, both economically and socio-culturally.

\section{METHODS}

This research used a qualitative research approach. Through this approach, it showed about the life, behavior, social movements, and kinship relations among people. According to Maleong [6] it is used to find and understand what is hidden behind the existing phenomenon or symptom. Bodgan and Taylor [7] stated that in qualitative research methods, researchers can create and compile essential concepts, and these are not found in other methods.

To deeply analyze the forms of exploitation in child labor, researchers used a case study research method in which the study unit was a group. The research subjects were children that worked in tourism distribution centers on the island of Lombok, so that the unit of analysis was carried out at the individual level (child labor), and to check the validity of the data from the case study results, the following activities were carried out: 1) triangulation of data sources in which it was carried out by means of seeking data from many sources of informants and research subjects. 2) triangulation of data collection methods (observation, interviews, documentary studies. 3) theory triangulation (emic and ethics), by examining relevant theories in which multiple theories were used [8].

The analytical phase began with; (1) open coding which includes the process of breaking down, examining, comparing, conceptualizing, and categorizing data. (2) axial coding stage in which the results had been obtained from open coding was reorganized based on categories to be developed towards propositions. (3) In the selective coding stage, the researcher classified the process of examining the core category in relation to other categories. Core categories were found through a comparison of category relationships. Next, examining the category relationships and conceptualizations. And finally, drawing a conclusion that was appointed to be a general design. Furthermore, to determine the validity of the data, namely the degree of credibility of the research findings, the researcher involved the participants to examine the data and interpretation, and to check whether the results of this study could provide meaningful input to the community, public consultation and seminar of resultswere conducted. Through the seminar, input was obtained to increase the credibility of the findings of this research [8].

\section{RESULTS AND DISCUSSION}

This part of the article describes the data covering the characteristics of child labor, patterns of time used, and patterns of energy used by child laborers.

\section{Characteristics of The Child Labour.}

This research has conducted interviews with 160 child laborers. Judging from the gender, $84(52 \%)$ boys and 78 (48\%) girls. Then from the aspect of age, as many as 54 children $(33.7 \%)$ were 6-10 years old, and $106(66.3 \%)$ were 11-15 years old.

As for the average level of education of child laborers, the following data were obtained; never went to school 3 people, kindergarten 3 people, elementary school 97 people, and 57 people were studying in junior high school. In this study, the family conditions of child laborers had been identified, namely: (1) The types of work performed by the parents of child laborers are; traders, laborers, servants, and farmers. (2) The marital status of the parents of child workers. In this study, the data obtained indicate that their parent's marital status is as follows; 127 children in which their parental status is still intact, 23 children in which their parents have divorced, 3 children in which their parents have polygamy, and 7 children in which their parents have passed away. As for the type of work of their parents can be seen in Table I.

TABLE I. Types of Parents' Job
\begin{tabular}{|c|l|c|c|}
\hline No. & \multicolumn{1}{|c|}{ Job } & Amount & $\%$ \\
\hline 1 & Jobless & 15 & 9,4 \\
\hline 2 & Street vendor & 54 & 33,7 \\
\hline 3 & Labourer & 13 & 8,1 \\
\hline 4 & Tourist Guide & 1 & 0,6 \\
\hline 5 & Cattleman & 5 & 3,1 \\
\hline
\end{tabular}




\begin{tabular}{|c|l|c|c|}
\hline No. & \multicolumn{1}{|c|}{ Job } & Amount & \% \\
\hline 6 & Fisherman & 25 & 15,6 \\
\hline 7 & Parking attendants & 2 & 1,3 \\
\hline 8 & Traditional boat captain & 2 & 1,3 \\
\hline 9 & Farmer & 34 & 21,3 \\
\hline 10 & Security & 1 & 0,6 \\
\hline 11 & Laborers outside of Indonesia & 4 & 2,5 \\
\hline 12 & Craftsman & 4 & 2,5 \\
\hline & Sum & $\mathbf{1 6 0}$ & $\mathbf{1 0 0}$ \\
\hline
\end{tabular}

Source. Primary Data, 2020

In this research, various types of work performed by children were identified, they were: street vendors, buskers, parking attendants, fishermen, photographers, and surfing instructors. Meanwhile, the status of the business or work they were currently doing were: (1) Their own or their parents' business is (107) children or around $66.8 \%$. Meanwhile, the businesses belong to other people as many as 53 children $(33 \%)$.

TABLE II. Types of Children's Job

\begin{tabular}{|l|l|c|r|}
\hline No. & \multicolumn{1}{|c|}{ Types } & Amounts & \multicolumn{1}{c|}{$\%$} \\
\hline 1 & Photographer & 5 & 3,1 \\
\hline 2 & Surfing Instructor & 4 & 2,5 \\
\hline 3 & Fisherman & 6 & 3,7 \\
\hline 4 & Parking attendant & 5 & 3,1 \\
\hline 5 & Street vendor & 129 & 80,6 \\
\hline 7 & Busker & 11 & 6,9 \\
\hline \multicolumn{3}{|r|}{ Source: Primary Data, 2020 } \\
\hline
\end{tabular}

\section{The Pattern of Working Time}

The data description on the patterns of time spent by child laborers in this study relates to (1) the Experience of being a worker. This research identifies the following years of experience as a worker: 2 months (16 children), one year (43 children), 2 years ( 27 children), 3 years ( 34 children), 4 years ( 14 children), 5 years ( 12 children), and 6 years ( 14 children). (2) Time to do work. This research identified the patterns in the use of their to-do work; 18 people $(11.25 \%)$ in the morning, 75 people (47\%) in the morning, only 24 during the day $(15 \%)$, and 18 people working from evening tonight (11.25\%). (3) Their goals for work. In this research it was also identified that their goals for work are as follows: just to join friends, help their parents, and to earn money for shopping (4) Time to do school assignments (homework). There are several options they can do to do their homework from school, namely: doing it at night, not doing it, while working, off-shifts, right after school, after working.

\section{The patterns of Energy Spent}

This section describes the patterns of energy spent by the child laborers, namely those related to (1) the activity they did before doing the main work. (2) the one orderingto work, (3) the wages/benefits received, and (4) the use of the wages received.

The results of this study indicate that before doing their main work, they do work activity as; Go to school, help parents at home, and prepare equipment for working. This research has identified that those that order them (child laborers) to work are: their parents, their families, and other people. The results of this study also found that during work, about 60 children (37\%) got wages, and $100(62.5 \%)$ did not get wages.

\section{Discussion}

This part discusses the forms of exploitation experienced by child laborers such as exploitation of age, working hours, wages, physical exploitation, and social exploitation that occur in the tourism industry.

\section{Age Exploitation}

This research found that age exploitation is indicated by the number of child laborers that work under the general age for laborers, that is 18 years old. In this research, the lowest age is 6 years and the highest is 15 years.

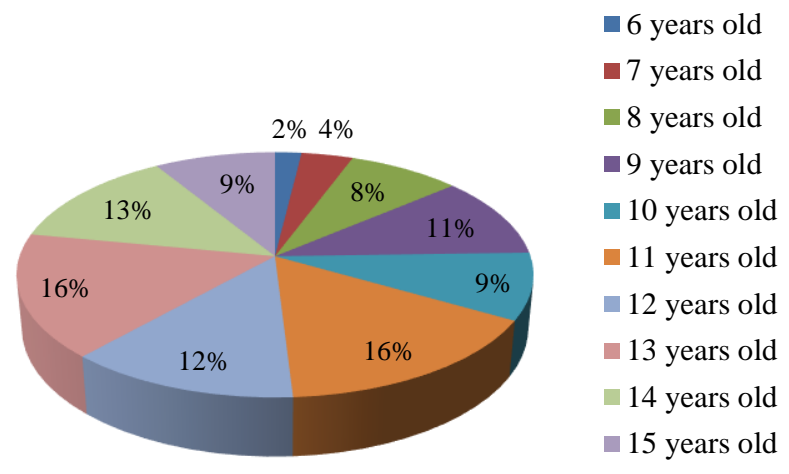

Fig. 1. The General Average of Child Laborer

This data shows that the age factor is not a consideration for parents in employing children to earn income. Even though children that work are not in accordance with the age of the child and are not considered that the children would experience physical and non-physical problems. In this research, the reasonfor underage children ordered to work by parents and others are the children can be paid cheaply, easy to manage, and are not demanding. Data in the field shows that child laborers in the tourism industry arekids and teenagers. The average age of working children is from the age of 6-15 years and some are still attending elementary and junior high school and some even dropping out of school.

The results of this research are in line with the findings suggested by Effendi, Viryani, and Priyarsono (2013) that the age of exploitation of children for work is caused by the existence of First, the strategy carried out by parents for household survival. According to them, rural communities that experience transition and communities that are poor will take advantage of the available resources during economical changes. One of the efforts made is to use family labor. Usually, children are also included in supporting the economic life of the family. Second, there is a transition to industrialization. The growth of industrialization requires the cultivation of capital to increase production. Usually, entrepreneurs want to reduce production costs. A way to overcome this problem is to seek child labor because it can be paid at low wages but has a high level of productivity.

\section{Exploitation on Working Hours}

The data shows that child laborers work at different times, some are part-timers and some are full-timers. The long working hours make children lose time to study, rest, and play, which are part of children's rights that must be fulfilled. The exploitation of children seen from the working hour is included in the type of subordination under certain individual, in this case, the parents of the child laborers, since the 
working hours of children have been regulated by their parents beyond the limits stipulated by the labor law [9].

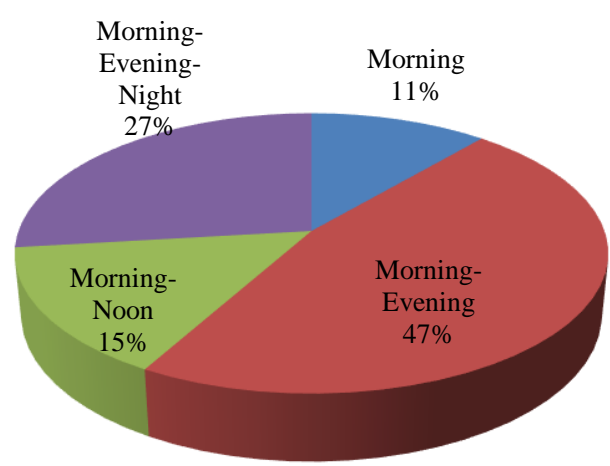

Fig. 2. The Average Pattern of the Working Hours

\section{Wages Exploitation}

Based on the results of the research that has been conducted, the wages of the children tend to be left to other people, especially their parents, and used for school tuitions and household purposes. Child laborers are not paid according to their hard work, the wages given by those who provide work were low even before the wages were divided into school tuitions and household purposes. The Data indicates that child laborers received wages that did not match the results of their work, $66.8 \%$ even did not get wages because the job they did belong to their parents. Meanwhile, the job that belongs to other people is $33 \%$. Children who get their wages only get from IDR1000-IDR5000 per day.

The results of this study are in line with the research of Saleh and Muhammad [10] that the low wages of child labor and the absence of wages given to children that have helped contribute their income to support family income are terrible while the length and the workload are quite heavy. However, in this case, the parents indirectly break the dream of the child because the results of the work they get that should be saved have been taken over by the parents. This condition shows that children that work are not to fulfill their own needs, but rather to meet the economic needs of the family [11].

$$
\begin{aligned}
& \text { - Parents Family } \\
& \text { - Others }
\end{aligned}
$$

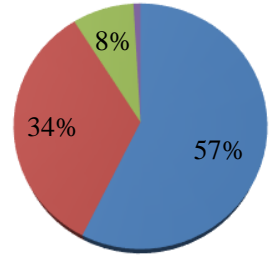

Fig. 3. The Average of Family that Order Children to Work

\section{Social Exploitation}

This study found that social exploitation that occurs in children is in the form of feelings of shame, jealousy with friends, hatred, and marginalization by friends in the social environment. When they are invited to go out to play together, they cannot come because they have to do and finish the job. This social condition causes the child's immortality to be obstructed. This is supported by the results of the findings that there is humiliation, rejection, withdrawal, or avoidance of associations with peers so that it affects children's emotional development [12].

In addition, the social exploitation experienced by children in the tourism service industry was physical and energy manipulated by parents and other people. The time that is used to work during the day, in fact, some children are ordered to work until evening. Children should have rested after school is ordered to work, they do not have time to rest and cause them to experience physical problems such as lack of sleep. Child laborers are demanded or asked by their parents to work so that they can be independent and can earn their own money. In general, child laborers are not only in a powerless position but are also very vulnerable to socioeconomic exploitation. In the service industry sector, they are in conditions of long working hours, low wages, some jobs face the risk of work accidents, and health problems, harassment, and abuse from adultsat work [13].

\section{IV.CONCLUSION}

Research on child labor in the tourism industry can be concluded as follows: the forms of exploitation experienced by child laborers in the tourism industry are; exploitation of age, exploitation of working time, exploitation of wages, and exploitation of society.

The phenomenon of exploitation of child laborers that occurs in tourist destinations on the island of Lombok, the local government needs to approach parents so as not to employ underage children, so that parents have a high awareness of educating their children. In addition, it is very necessary to empower children to be given scholarships so that they are motivated to go to school. To their parents, the government also needs to increase their capacity and skills on how to do entrepreneurship and provide capital for entrepreneurship.

\section{ACKNOWLEDGEMENT}

The researchers would like to thank: (1) the Rector of the University of Mataram that has provided research funding which comes from internal university funds (NonTax State Revenue or PNBP), through the Research Program for Capacity Building for the 2020 funding year contract number 2612 / UN18.L.1 / PP / 2020. (2) The Institute for Research and Community Service, the University of Mataram that has recommended conducting research. (3) The authors also express their gratitude to all the informants and research subjects that have provided information during the research.

\section{REFERENCES}

[1] Suyanto, Bagong. "Masalah Sosial Anak". Surabaya. Kencana Prenada. 2013

MediaGroup.

[2] Sulistiani, Kurni Dewi. "Fenomena Kehidupan Anak Pekerja Ojek PayungDi Malioboro". Universitas Negeri Yogyakarta: Yogyakarta. 2014.

[3] Iryani, Beta Septi, and D. S. Priyarsono. "Eksploitasi terhadap Anak yang Bekerja di Indonesia." Jurnal Ekonomi dan Pembangunan Indonesia 13.2 2013: 177-195.

[4] Purnama, Indah A. "Pekerja Anak Pada Usaha Kerajina Ketak(Studi Di Dusun Nyurbaye Desa Batu Mekar Kecamatan Lingsar Kabupaten Lombok Barat)", (A Thesis). FKIP University of Mataram. 2019 
[5] S Sofian, Ahmad. "Kompleksitas masalah pekerja anak di Indonesia." Populasi 8.21997.

[6] Maleong, J.L "Metode Penelitian Kualitatif". Bandung: PT. RemajaRosdakarya 2014.

[7] Bodgan, R \& Steven Taylor "Dasar-Dasar Penelitian Kualitatif". Surabaya: Usaha Nasional Surabaya. 2003.

[8] Syafruddin, Syafruddin, Hairil Wadi, and Suud Suud. "Tourism Industry and Women's Employment Mobility in the Special Economic Zone (SEZ) of Mandalika Kuta Lombok." Society 8.1 2020: 136-146.

[9] Lao, Terence T., et al. "Advanced maternal age and postpartum hemorrhage-risk factor or red herring?." The Journal of MaternalFetal \& Neonatal Medicine 27.3 2014: 243-246.

[10] Saleh, Saiful, Muhammad Akhir, and B. Sisma. "Eksploitasi Pekerja Anak Pemulung." Equilibrium: Jurnal Pendidikan 6.1 2018: 10-20.

[11] Endrawati, Netty. "Faktor Penyebab Anak Bekerja dan Upaya Pencegahannya." Jurnal Ilmiah Hukum-Refeksi Hukum 2011.

[12] Prajnaparamita, Kanyaka. "Perlindungan Tenaga Kerja Anak." Adminitrative Law \& Governance Journal 1 2018: 112-128.

[13] Perdana, Novrian Satria. "Dinamika Pekerja Anak: Studi Kasus Pekerja Anak pada Sektor Informal di DKI Jakarta." ATIKAN 8.1 2018. 